\title{
Dying the right-way? Interest in and perceived persuasiveness of parochial extremist propaganda increases after mortality salience
}

\section{OPEN ACCESS}

Edited by: Robert Böhm,

RWTH Aachen University, Germany

Reviewed by:

Simon Schindler,

University of Kassel, Germany Benjamin P. Lange,

University of Wuerzburg, Germany

${ }^{*}$ Correspondence:

Lena Frischlich,

Department of Psychology, University of Cologne, Richard-Strauss-Straße

2, 50931 Cologne, Germany lena.frischlich@uni-koeln.de

Specialty section: This article was submitted to Evolutionary Psychology and Neuroscience, a section of the journa Frontiers in Psychology

Received: 16 May 2015 Accepted: 03 August 2015 Published: 14 August 2015

Citation:

Frischlich L, Rieger D, Hein M and Bente $G$ (2015) Dying

the right-way? Interest in and perceived persuasiveness of parochial extremist propaganda increases after mortality salience.

Front. Psychol. 6:1222. doi: 10.3389/fpsyg.2015.01222

\author{
Lena Frischlich $^{1 \star}$, Diana Rieger ${ }^{1,2}$, Maia Hein ${ }^{3}$ and Gary Bente ${ }^{1,4}$ \\ ${ }^{1}$ Department of Psychology, University of Cologne, Cologne, Germany, ${ }^{2}$ University of Mannheim, Mannheim, Germany, \\ ${ }^{3}$ Academia for Applied Psychology and Psychotherapy, Cologne, Germany, ${ }^{4}$ Michigan State University, East Lansing, MI, \\ USA
}

Research on parochial altruism demonstrated that hostility toward out-groups (parochialism) represents the dark side of the willingness to benefit one's in-group even at own costs (altruism). Parochial aggression thereby emerged mainly under conditions of threat. Extremist propaganda videos, for instance by right-wing extremists, try to capitalize on parochial altruistic mechanism by telling recipients sharing their national identity that this nation is under threat wherefore they for have to join the extremist's cause to prevent the extinction of their nation. Most of the time, propaganda videos are rated as uninteresting and non-persuasive by the target audience. Yet, evolutionary media psychology posits that the interest in and effectiveness of media increases when evolutionarily relevant problems are addressed. Consequently, interest in parochial altruistic right-wing extremist messages should increase under conditions of threat. The current study tested this assumption by randomly assigning German non-Muslims ( $N=109)$ to either an existential threat (here: mortality salience) or a control condition and asking them to evaluate extremist propaganda that addressed them as either ingroup members (right-wing extremists) or as out-group members (Islamic extremists). In support of the hypotheses, subjects under conditions of threat reported a higher interest in the right-wing extremist propaganda and perceived it as more persuasive. We discuss the results concerning the implications for evolutionary media psychology and the transmission of parochial altruism in propaganda videos.

Keywords: Parochial altruism, mortality salience, right-wing extremism, propaganda, persuasion

\section{Introduction}

Extremist propaganda videos have become a frequent part of the contemporary online landscape. In Germany in particular, right-wing extremists such as the "Oldschool Society" and Islamic extremists such as the "Islamic State" use YouTube videos to target recipients who share their nationality or religion in order to gain new followers (Bayrisches Staatsministerium des Inneren für Bau und Verkehr, 2014). Via these videos, the propagandists try to convince the recipients that their nation (respectively, religion) is menaced by extinction (Godall, 2010; Halverson et al., 2011; Kruglanski et al., 2013) due to the "the system" or "the West" and that they have to join the propagandist's fight and be willing to risk life and limb to preserve their group. 
The so propagated behaviors of supporting one's in-group members, even at the cost of one's own resources (altruism), and of aggressively fighting out-groups (parochialism) has gained substantial attention in recent years from evolutionary psychological research under the concept of parochial altruism (Choi and Bowles, 2007; Bowles, 2008). Evidence gathered in different research areas has demonstrated that parochial aggression toward out-groups and altruistic cooperation with in-group members are deeply interwoven (Bornstein and Erev, 1994; Rusch, 2014), whereby "people go to war" (Böhm et al., 2015) to defend their fellows. It is on this defense of those sharing one's national or religious identity against the "wicked enemy" that extremist propagators capitalize (Lasswell, 1927). Yet their open call for parochial aggression stands in sharp contrast to contemporary egalitarian norms (Pettigrew, 1995). And, of course, neither the majority of Germans nor the majority of Muslims shares the extremist propagators' attitudes (Decker et al., 2012; Frindte et al., 2012). Prior research demonstrated propaganda to be evaluated very negatively and recipients to deny the effects of propaganda (Arendt, 2015). Moreover, in contrast to the propagators' aims, propaganda was evaluated even more negatively when it was directed to the recipients' national or religious in-group (versus to another audience; Rieger et al., 2013). Nevertheless, single videos can raise interest and become viral (Glaser, 2013), and propaganda has been discussed as persuading individuals from radical ideologies (Dilanian and Bennett, 2013). Although interest in propaganda does not necessarily lead to radicalization, it is a necessary precondition for further exposure to such messages (McCauley and Moskalenko, 2008; Wilner and Dubouloz, 2009) and an initial step in a potential persuasion processes (Lewis, 1903).

In the current paper, we examined the effects of extremist propaganda from an evolutionary media psychological perspective. We built upon the assumption that media allows the recipient to simulate experiences relevant to his or her level of evolutionary fitness (Tooby and Cosmides, 2001) without "risking life and limb in the real world" (Schwab and Schwender, 2010, p. 31). Media features are recognizable as "design features of an evolved system whose biological function is learning" (Vorderer, 2006, p. 14). Following Schwab (2010) media pique interest when evolutionary problems, such as the threat by predators (Tooby and Cosmides, 2001) or hostile intergroup conflicts are displayed. Thus, the conditions under which parochial altruism increases-namely, the perception of threat and vulnerability (De Dreu et al., 2010; Rusch, 2014; Böhm et al., 2015) - most plausibly also increase the interest in parochial propaganda. Note that we do not suggest that recipients are "entertained" by propaganda such as by entertaining media (Ohler and Nieding, 2006). Instead, we assume that "media events are produced by people for people, they are geared to human needs" (Schwab and Schwender, 2010, p. 21). A larger effectiveness of propaganda thus should be mirrored in a higher perceived persuasiveness of these videos.

\section{Parochial Altruism and the Role of Threat}

From a Darwinian perspective human social behavior has developed throughout phylogenies via the adaptation to natural conditions and in order to increase the individual's fitness and maximize its reproductive success (West et al., 2011). Acts of altruism (Hamilton, 1964a,b; Zahavi, 1995) and parochial aggression toward out-groups (Choi and Bowles, 2007) are both puzzling, as they can impair individuals' fitness by reducing resources and hampering lucrative trading. Theories that take only an individual-level perspective on altruistic (or aggressive) behavior such as kin selection (Hamilton, 1964b; Riolo et al., 2001) or reciprocal altruism (Trivers, 1971; Axelrod and Hamilton, 1981) have failed to explain altruism to non-kin, such as the behavior called for by extremist propaganda, when reciprocation is unlikely.

Recent theories on parochial altruism are more promising for explaining, for instance, self-sacrifices in the name of one's religion (Ginges and Atran, 2009; Ginges et al., 2009) or nation (De Dreu et al., 2014). In contrast to prior theories, the concept of parochial altruism considers both the intragroup and the intergroup level of behavior (Arrow, 2007). Humans are social animals, and group membership increases their odds for survival throughout phylogenies far beyond what would have been possible for a single individual (De Dreu et al., 2014). Thus, humans' self-interest evolved mitigated by their group membership (Brewer and Carporael, 2006). On the intragroup level, altruistic individuals have a lower direct fitness (because altruism is costly). On the intergroup level, however, altruistic individuals increase the fitness of the group by investing more in that group and therewith increase the individuals' indirect fitness (Arrow, 2007). Choi and Bowles (2007) provided evidence for this assumption by simulating groups of agents (tolerant versus parochial, altruistic versus selfish) that interacted with each other over thousands of generations under conditions likely to represent human interactions in early times of humankind. Violent conflicts in this simulation were likely when parochialists formed the majority of at least one group in that interaction. Furthermore, only parochial altruists ("warriors") actively engaged in intergroup fighting (non-altruists would not be willing to do the fighting themselves, and tolerant others would prefer to peacefully interact with the out-group). The results demonstrated that groups with more parochial altruists not only engaged in more conflicts but also tended to win these wars. The societies that emerged within this simulation were stable when parochial altruists or selfish but tolerant trades formed the majority.

Of note, the willingness to parochially aggress out-groups has been observed mainly under conditions of conflict (Bornstein et al., 2002; Halevy et al., 2008; Abbink et al., 2012) when subjects perceived themselves as vulnerable (Böhm et al., 2015), wanted to protect their in-group members (Rusch, 2014), or wanted to sanction someone who had threatened their fellows before (Bernhard et al., 2006). For instance, De Dreu et al. (2010) found subjects to preemptively strike against out-group members in an intergroup prisoner dilemma only when they feared that their in-group would lose resources due to future outgroup actions. This is highly compatible with social psychological research demonstrating how threat motivates intergroup biases (Hewstone et al., 2002). 
Beyond threats to concrete in-group members, symbolic threats (Stephan et al., 2000; Hewstone et al., 2002; Hogg et al., 2010) can also foster parochial altruism. In particular, research inspired by terror management theory (Greenberg et al., 1986) repeatedly demonstrated existential threats resulting from reminders of one's own mortality (mortality salience, MS) to increase the acceptance of parochially altruistic in-group members (for a review, see Pyszczynski et al., 2008). For instance, Greenberg et al. (2001) demonstrated that, in the absence of MS, white Americans evaluated a white American who claimed to be "proud of being white" as more racist than someone who claimed to be "proud of being black." This effect disappeared under conditions of MS. Similarly, Pyszczynski et al. (2006) found US participants to be more accepting of violent military attacks on Muslim out-group members, and Iranian students to offer a more favorable evaluation of someone expressing parochial altruistic anti-US and pro-martyrdom attitudes under conditions of MS.

With its parochially altruistic content, extremist propaganda most plausibly reaches its targeted audience only after a perceived threat has made these recipients vulnerable to the parochially aggressive narrative. We tested this assumption by conceptually replicating the study by Rieger et al. (2013) on the evaluation of right-wing extremist and Islamic extremist propaganda videos. More precisely, we compared the effects of MS versus a control topic on the evaluation of these propaganda videos in a German student sample. Rieger et al. (2013) found German students to report less interest in and persuasiveness of right-wing extremist as compared to Islamic extremist propaganda, but we predicted that, under conditions of threat, German students would report increased interest (H1) in the right-wing extremist propaganda and perceive the videos as more persuasive (H2). Moreover, increased interest should be positively associated with an increased persuasiveness ascribed to these videos (H3).

Beyond our central questions, our study also had a pair of secondary objectives. First, we expected the effects of MS to represent a general response to parochial altruistic propaganda addressing them as in-group members via their nationality. Consequently, we expected the effects to explain additional variance beyond political or ideological attitudes (e.g., authoritarianism) that have been reported previously to predict interest in extreme ideologies (Altemeyer and Hunsberger, 1992; Fuchs, 2003; Sibley and Duckitt, 2008; Rieger et al., 2013). Second, we wanted to check for gender differences. Prior research often relied on male samples for studying parochial altruism (De Dreu, 2012) or the effects of extremist propaganda (Rieger et al., 2013). Studies including both genders report mixed results. Some studies find stronger parochial aggression among males (Yuki and Yokota, 2009) and parochial aggression to be positively associated with levels of testosterone (Reimers and Diekhof, 2015). Other studies report no gender differences in the acceptance of parochial altruism (Ginges et al., 2009). Finally, Rieger et al. (2013) identified three more factors on which the evaluation of extremist propaganda varied: shame and aversion after the reception and the one-sidedness ascribed to the propaganda videos. They report German students to respond with increased levels of shame to right-wing extremist videos and to evaluate these videos as more one-sided than Islamic extremist videos (aversion ratings did not differ). We wanted to explore whether MS would attenuate these findings.

\section{Materials and Methods}

We examined our predictions by presenting German students under conditions of MS (versus a control topic) with parochially altruistic extremist propaganda, addressing them as in-group members (through right-wing extremist videos targeting "the Germans") or as out-group members (through Islamic extremist videos targeting "the Muslims"). The last factor served as a within-subjects factor.

\section{Sample}

$\mathrm{G}^{*}$ Power calculated that a sample of $N=92$ would be necessary to prove the smallest effect size observed by Rieger et al. (2013) for interest in right-wing extremist propaganda $(r=0.19)$. A total of 114 subjects finished our study (drop out $n=33$ ). To hold the group association between sender and recipient constant, we recruited only subjects who were born in Germany and did not self-identify as Muslims. Five participants did not fulfill these sampling criteria and were excluded from the analyses. The remaining $N=109$ (all German non-Muslims, 18 male) were on average 25.17 years old $(\mathrm{SD}=6.34)$. The majority of them $(94.4 \%)$ were students, while the remaining participants were already in the workforce. Gender, current profession (both $\left.\chi^{2}>1\right)$, and age $(F<1)$ did not vary depending on condition. The majority of our participants self-classified as Christians $(74 \%)$ or atheists $(23 \%)$; three subjects reported "another" religion. Religion was equally distributed among conditions, $\chi_{\text {exact }}{ }^{2}(3)=3.50, p>0.20$. On an 11 -point scale $(0=$ "totally unimportant," $10=$ "totally important") subjects rated their religion as rather unimportant for them $(M=3.08, \mathrm{SD}=2.81)$. Only two of the participants rated religion as "totally important" to them. Relevance of religion did not vary between conditions, $F<1$. On a 10 -point scale ( $1=$ "left-wing," $10=$ "right-wing"), subjects were rather left-wing oriented $(M=4.20, \mathrm{SD}=1.38)$. None of the participants was extremely right-wing oriented (Range 1-8). Political attitudes did not vary between conditions, $F<1$.

\section{Procedure and Materials}

Subjects were invited via German university mailing lists to participate in an online experiment about "political videos on YouTube." We rewarded them with the opportunity to participate in a lottery for two Amazon.de vouchers, each worth $30 €$. At the beginning of the questionnaire, subjects confirmed that they were over 18 years old and that they had read, understood, and accepted the ethical consent form. Afterward, they answered a set of demographic (age, nationality, religious identity, political attitude) and attitudinal questionnaires. To confirm that the effects we found were not solely attributable to interpersonal differences associated with hostile intergroup attitudes, subjects filled out a measure of authoritarianism (Petzel et al., 1997); violence acceptance 
(Wagner et al., 2002); anomia, their feeling of value lost (Fuchs, 2003); and self-esteem (Rosenberg, 1965). Subsequently, subjects were randomly assigned to either the MS or a control condition.

\section{Salience Manipulation}

Participants in the MS condition $(n=57)$ answered the standard two open-ended questions used in terror management research: (1) "Please briefly describe the emotions that the thought of your own death arouses in you." (2) "Please describe, as specifically as you can, what you think will happen to you as you physically die and once you are physically dead" (Rosenblatt et al., 1989). Participants in the control condition $(n=41)$ were given the same instructions, but the references to death were replaced with references to "failing an exam" (Monin, 2009).

\section{Delay}

Mortality salience affects intergroup attitudes only distally to death reminders, when the death-related thoughts are no longer in focal attention (Pyszczynski et al., 1999). Hence, to enable their distal defense subjects worked on a set of 35 raven matrices (Raven, 1998) before the next part of the experiment started.

\section{Video Exposure}

After the last matrix, participants watched two blocks of extremist videos in randomized order. Each block comprised three videos, either from right-wing extremists (total duration 07:58 min.) or from Islamic extremists (total duration 07:36 min.). We held the formats of the videos constant between the ideologies. We selected the videos from the database by Rieger et al. (2013). The videos in this database did not show explicit depictions of physical violence (such as beheadings) and were approved by the ethics committee of the German Federal Crime Police Office prior to data collection in their studies. Subjects in our study saw one talking head lifestyle activist video, one movie clip video, and one extreme clip video (see Supplementary Table S1, for a summary of their content).

\section{Dependent Measures}

Participants rated each video on the five scales that Rieger et al. (2013) introduced. The scales measured the participants' interest (e.g., "The video was interesting") in the videos, the videos' perceived persuasiveness (e.g., "After the video, I can understand the perspective of its producers better"), and the level of shame ("During the reception I felt shame") triggered by the video. Furthermore, we also measured subjects' level of aversion during the reception (e.g., "During the reception I felt disgust") and the one-sidedness ascribed to the video (e.g., "The video was sensational"), to ensure conditions similar to those in the studies by Rieger et al. (2013). Each of the 14 total items was evaluated on a four-point scale $(1=$ "totally not," $4=$ "totally").

\section{Check for Suspicion}

Finally, subjects were checked for suspicion and watched a video debriefing (05:06 $\mathrm{min}$ ) by the first author, supplemented by a written debriefing and the author's contact details.

\section{Results}

\section{Data Aggregation}

To ensure that participants had watched the videos, we subtracted the actual length of the video from the time subjects spent on the corresponding page. Subjects who did not watch the whole video received a negative difference; subjects who proceeded with the video after its end received a positive value (due to the response latency between the end of the video and the key pressure). To control for outliers, these scores were then $z$-standardized. Subjects with a negative value or with $z>3$ were treated as missing values for the respective video evaluation. Following the procedure by Rieger et al. (2013), we then computed mean scores for each of the dependent variables per ideology, resulting in one value per scale for both the right-wing extremist and the Islamic extremist videos. For the perceived persuasiveness ratings, the internal consistency for the aggregated right-wing extremist as well as the Islamic extremist videos was slightly questionable, both $\alpha=0.65$. All other scales $\alpha>0.70$.

\section{Preliminary Analyses}

We first examined the association of the included variables with each other via Pearson correlations. Political attitude, anomia, and violence acceptance were not significantly associated with the dependent variables, all $r<0.20$, hence these variables were excluded from the analyses thereafter (Field, 2013). Preliminary analyses of variance (ANOVAs) using the participants' characteristics as dependent variables revealed that subjects in the MS as compared to the control condition reported lower levels of self-esteem, $F(1,107)=8.24, p<0.05, r=0.27$. Consequently, the assumptions of analysis of covariance were not met (Field, 2013). Subjects did not differ regarding their level of authoritarianism, $F<0.1$.

Based on these findings, we analyzed the video evaluation via separate hierarchical regression analyses (see Weise et al., 2008 for a similar approach). Block 1 contained all variables measuring interindividual differences ( $z$-standardized) following the recommendation that predictors based on prior research should be entered first to partialize their effects out before the predictive value of the experimental manipulation is assessed (Field, 2013). Condition (dummy coded, $0=$ control, $1=\mathrm{MS}$ ) was entered in Block 2. To assess potential moderations, the two-way interactions between condition, authoritarianism, and self-esteem were entered in Block 3. Parameter estimates were based on 1000 bootstrap samples. The results for the simplest model including only condition as a predictor are provided in the Supplementary Table S2.

\section{Hypotheses Testing}

Regarding interest in the right-wing extremist videos, interindividual differences (Block 1) and their interactions with the condition (Block 3) failed to explain variance. As predicted in $\mathrm{H} 1$, condition (Block 2) significantly predicted interest, $F_{\text {change }}(1,96)=4.27, p<0.05$. Subjects under conditions of MS reported more interest in the right-wing extremist propaganda than did subjects in the control condition. None of 
the models explained the interest in the Islamic extremist videos, all $p \geq 0.20$.

Hypothesis 2 predicted that subjects under conditions of MS would perceive the in-group propaganda as being more persuasive. Block 1 (containing the interindividual differences) reached significance, $F_{\text {change }}(4,94)=3.17, p<0.05$. Higher levels of authoritarianism predicted higher perceived persuasiveness of the right-wing extremist videos. What is more relevant, Block 2 also reached significance, $F_{\text {change }}(1,93)=6.92, p=0.01$. Subjects in the MS condition perceived the extremist in-group messages to be more persuasive than did control subjects. The effect of authoritarianism remained stable. Block 3 failed to explain further variance (see Table 1). None of the models explained the perceived persuasiveness of the Islamic extremist videos, all $p \geq 0.20$.

In line with the expectation formulated in $\mathrm{H} 3$, correlational analyses showed that interest and perceived persuasiveness for the right-wing extremist videos were strongly associated in the MS condition $=0.67, p<0.001$, and had a lower but still significant association in the control condition, $r=0.30$, $p<0.05$.

\section{Additional Analyses}

Following the procedure by Rieger et al. (2013), our study also included measures of shame, aversion, and one-sidedness. MS had no effects, however, on either reported aversion or onesidedness ascribed to the videos. Regarding shame after the rightwing extremist videos, only Block 2 (condition) reached marginal significance, $R_{\text {change }}{ }^{2}=0.04, F_{\text {change }}(1,93)=3.70, p<0.06$. Subjects in the MS condition reported more shame after the right-wing extremist messages than did subjects in the control condition $(b=0.22, \mathrm{SE}=0.10, \beta=0.20$, CI $[-0.33,0.05]$; see Supplementary Table S3). All other models failed to reach significance, all $p>0.20$. Shame reported after the Islamic extremist videos, in contrast, was significantly predicted by Block $1, R^{2}=0.13, F_{\text {change }}(4,93)=3.39, p=0.01$. Higher self-esteem predicted lower levels of shame $(b=-0.30, \mathrm{SE}=0.08, \beta=-0.36$, $\mathrm{CI}[-0.45,-0.13])$. All other models failed to reach significance, all $p \geq 0.20$. Pearson correlations showed that shame had a moderate association with interest, $r=0.33, p<0.05$, and perceived persuasiveness, $r=0.43, p<0.001$, in the MS condition but not in the control condition (all $p>0.10$ ).

The results so far suggest that interest and shame might increase the perceived persuasiveness of the videos. We explored this idea via a mediation analysis using the PROCESS macro by Hayes (2012). We entered condition as a predictor variable $(0=$ control, $1=\mathrm{MS})$, interest and shame as mediators, and authoritarianism as covariate ( $z$-standardized). The results showed that the effect of MS on the perceived persuasiveness of the right-wing propaganda was significantly mediated by interest, $a b=0.08, \mathrm{SE}=0.06$, CI $[0.002,0.21]$, but also by shame, $a b=0.04, \mathrm{SE}=0.03$, CI $[0.005,0.12]$. The contrast between these two failed to reach significance, $\mathrm{C}_{1}=0.03$, $\mathrm{SE}=0.07$, CI $[-0.07,0.18]$. Meanwhile, the total effect of MS on perceived persuasiveness was significant; the direct effect when both mediators were included was only marginally significant (see Figure 1).

\section{Discussion}

Right-wing extremists and Islamic extremists propagate parochial altruism to recipients sharing their national or religious identity via Internet videos. Evolutionary media psychology posits that the response to media content works on evolutionary mechanics, whereby media content displaying evolutionary relevant problems (such as parochial altruism in hostile intergroup interactions) creates larger interest (Tooby and Cosmides, 2001; Schwab and Schwender, 2010). Drawing upon research finding that threats increase parochial altruistic behavior in humans, we predicted that existential threats-namely, reminders of one's mortality-would increase the interest in and the perceived persuasiveness of extremist propaganda. Overall, the results confirmed our expectations. German students reported an increased interest in right-wing extremist videos under conditions of MS (Hypothesis 1) and ascribed these videos a larger persuasiveness (Hypothesis 2). Interest and perceived persuasiveness were positively associated (Hypothesis 3). Moreover, additional mediation analyses demonstrated that interest partially mediated the association between MS and perceived persuasiveness. The effects of MS emerged after interpersonal differences in factors such as authoritarianism, self-esteem, or gender were partialized out, underlining the assumption that the response to parochial altruistic in-group members represents a general mechanism. Overall, our findings confirm prior research on parochial aggression (De Dreu et al., 2010; Rusch, 2013; Böhm et al., 2015) and the acceptance of parochially aggressive in-group members (Pyszczynski et al., 2006; Kugler and Cooper, 2010) after MS, and extended these findings to the area of media psychology. Further, MS did not affect the response toward the Islamic extremist videos underlining the crucial role of being addressed as in-group member (and not, for instance, the interest in extremist messages per se (Hogg, 2014).

Beyond our predictions, we also found MS to increase participants' levels of shame after exposure to propaganda videos addressing the recipient as an in-group member. Shame further partially mediated the effects of MS on the perceived persuasiveness of the videos. Albeit prior evidence on the relationship between shame and hostile intergroup attitudes is somewhat mixed (Brown et al., 2008; Piff et al., 2012), our results confirm studies showing that shame can motivate parochial aggression (Tangney et al., 1992; Lickel et al., 2005). Nevertheless, the bootstrapped confidence intervals encompassed zero, so our findings should be interpreted cautiously and future studies exploring the role of shame in more detail are necessary.

Overall, our results are meaningful on both a theoretical and an applied level. On a theoretical level, they transfer the perspective of parochial altruism to media psychology. In so doing, they extend earlier theories by showing that not only entertainment (Ohler and Nieding, 2006; Schwab, 2007) but also the response to hostile media evolved from evolutionary adaptive processes. In light of our results, propaganda might be the medium that makes "people go to war" (Böhm et al., 2015). Moreover, our results fit current communication research demonstrating that media satisfy basic human needs (Bartsch 


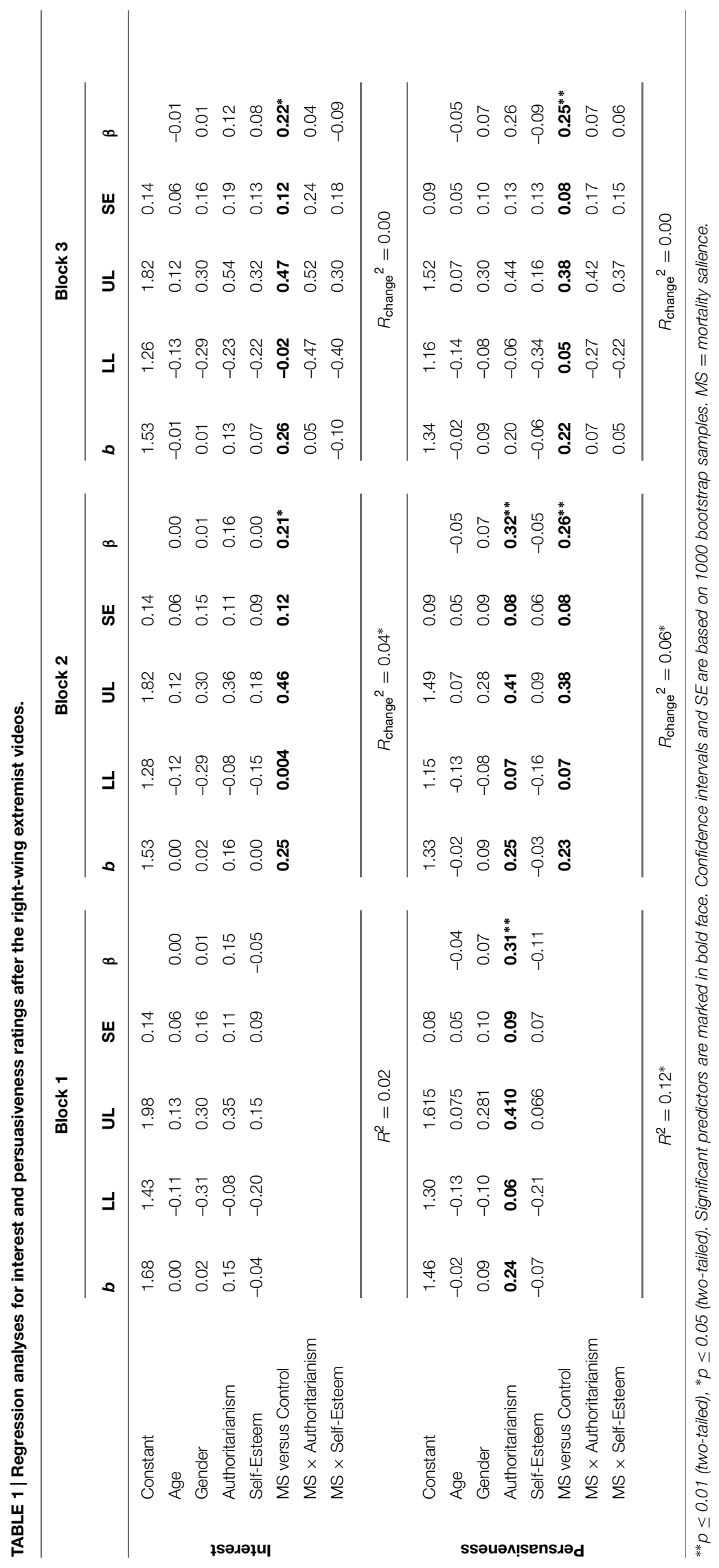




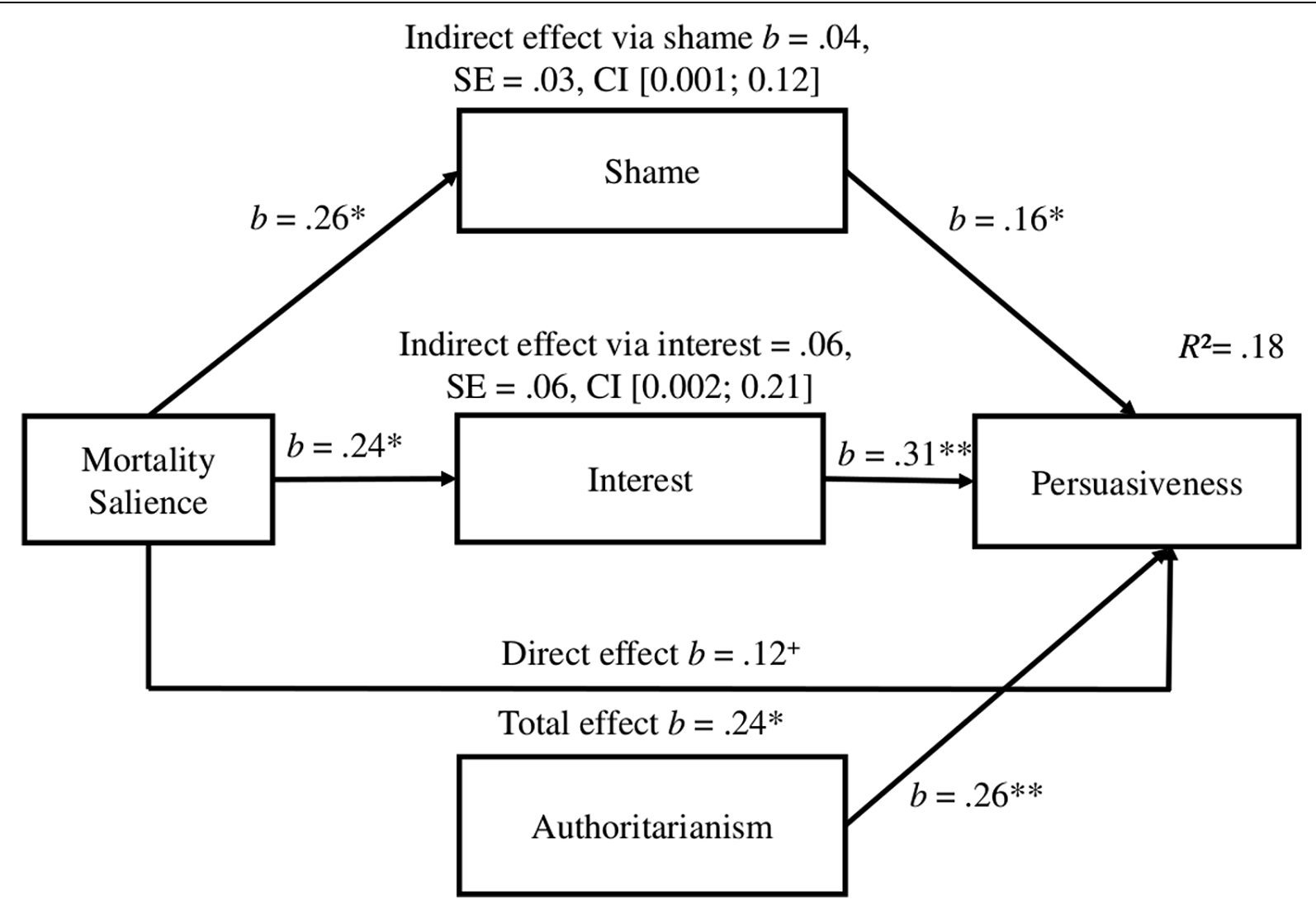

FIGURE 1 | The effect of mortality salience on the perceived persuasiveness of right-wing extremist videos mediated by shame and interest. ${ }^{* *} p>0.01,{ }^{*} p>0.05,{ }^{+} p>0.10$. Parameter estimates are based on 1000 bootstrap samples.

and Schneider, 2014; Roth et al., 2014). Our study suggests that incorporating evolved needs into such theory building might enhance our understanding of media consumption and effects.

Moreover, our findings add to the growing evidence that media serve an anxiety-buffering function (Rieger et al., 2015). Notably, even under conditions of threat, subjects did not react enthusiastically to the propaganda messages; the effects remained small. Yet our finding matches prior studies showing that individuals (in experimental research) overall are not very hostile toward out-group members at all; instead, parochial aggression manifested, for instance, in the refusal to help outgroup members (Weisel and Böhm, 2015). Luckily, the exclusive reliance on parochial altruistic behaviors is relatively seldom (De Dreu et al., 2015).

Nevertheless, not all individuals have to serve as "warriors" in intergroup conflicts; accepting them as the dominant group also allows them to foster violent intergroup encounters (Choi and Bowles, 2007). From a media psychological perspective, allowing extremists to voice their opinion might, via spiral process, create the illusion that they already form the majority and therefore reduce anti-extremist voices (Glynn et al., 1997).

On an applied level, the wide distribution of extremist propaganda makes our effects although they are small interesting for practitioners. For instance, our effects were irrespective of gender, suggesting that the current susceptibility of young women listening to the propaganda of Islamic extremists reported by mass media (Wahba and Simon, 2014) might also work on evolved mechanics. Research focusing on gender differences in the context of parochial altruism and extremism could provide meaningful insights here.

In addition, understanding the parochial altruistic mechanisms of propaganda effects could help to attenuate the influence of such videos. For instance, the salience of a certain social category (such as resulting by being addressed as "German" in a right-wing extremist video) is a fluent process and depends on the (potential) cooperation between in-group members. Albeit, we observed MS to increases the interest in extremist messages even among recipients with moderate political attitudes, as long as the videos capitalized on the shared social category, such categorizations are not stable. Kurzban et al. (2001) found that even dominant cues such as ethnicity (Cosmides et al., 2003; Xiaojing et al., 2009) are attenuated by making other group memberships salient. Consequently, distributing so-called counter-narratives (Ashour, 2010) capitalizing on shared group identities (e.g., being human) could enhance altruism toward others beyond one's national group (Pyszczynski et al., 2008). 
Further, in the control group no interest in the parochial in-group propaganda was observed suggesting that removing threat could foster peace (Böhm et al., 2015). But also under conditions of threat, research demonstrating the effects of MS to be sensitive to salient norms (Jonas et al., 2008; Schindler et al., 2013), suggest that making norms of tolerance salient, for instance via counter-narrative media, could reduce the interest in parochial propaganda (Pyszczynski et al., 2008).

\section{Limitations}

Some limitations of the current study have to be noted. First, we used a typical student sample. Rieger et al. (2013) found opposed reactions by students and apprentices, therefore a replication of our study in a non-academic sample would be desirable. Prior research identified students as particularly nonsusceptible to in-group extremist propaganda; thus, the effects of MS we observed in this sample are particularly meaningful. Accordingly, replicating our study in a Muslim sample who are addressed as "in-group members" in Islamic-extremist videos would extend the generalizability of our findings. Noteworthy, parochial altruism as an evolutionary adaptive response should not depend on the cultural background of the recipients per se. Accordingly, MS has already been demonstrated to increase the acceptance of parochial aggressive in-group members among Iranian students (Pyszczynski et al., 2006). Further, we did not measure participants' subjective identification with nationality. Research has found that people highly committed to their group are more likely to accept parochial altruism (here: religious martydom; Ginges et al., 2010), so including such measures in future studies seems desirable. Nonetheless, parochial altruism has been observed in both minimal and real groups, suggesting that subjective identification is not enough to explain the response to parochially altruistic in-group members.

Regarding our design, it has to be pointed out that subjects participated in an anonymous online questionnaire. Although this format is highly compatible with real-life exposure to extremist Internet propaganda, we cannot dismiss the possibility that subjects might display different reactions offline. For instance, social identity de-individuation theory (Postmes et al., 1998) found subjects in anonymous online interactions to be even more prone to behaving according to situationally salient group memberships. Consequently, the evaluation of in- but also outgroup extremist propaganda might vary depending on whether a person watches such material alone online or together with others.

Concerning our materials, it has to be pointed out that we did not find effects of MS on the response to outgroup propaganda. At first sight, this contradicts studies showing harsher punishment of out-group terrorists under conditions of MS (Kugler and Cooper, 2010) or harsher punishments of out-group than of in-group perpetrators due to parochial altruistic motivations (Bernhard et al., 2006). However, we focused on positive responses to parochial aggressive propaganda and did not analyze the response to media narratives displaying the punishment of out-groups.
Our findings imply that such narratives (e.g., killing outgroup terrorists in Homeland) would also raise interest and be perceived as more persuasive (see Slater and Rouner, 2002, for the concept of narrative persuasion) due to parochially altruistic motivations. Furthermore, it should be noted that extremist propaganda itself can be regarded as threatening, and studies have shown that terrorism itself can induce death anxieties and trigger MS effects (Fischer et al., 2007; Das et al., 2009). Consequently, our participants might have perceived the Islamic extremist videos as more threatening than the right-wing extremist videos. Yet Rieger et al. (2013) found no significant differences in physiological arousal during the reception of the Islamic versus right-wing extremist videos, making this explanation implausible. Further, our selection differentiated between extremist videos offering the recipient to join their cause versus not. MS has been found to increase affiliation (Wisman and Koole, 2003). Consequently, examining the role of affiliation motives in this context in future studies is necessary to compare the turning toward different groups after MS.

As regards to our dependent variables, we focused on the interest in and the perceived persuasiveness of the videos. Although we based our dependent variables on prior research, these variables have to be interpreted cautiously. Interest is only an initial step in a potential process that might increase parochial attitudes and should not be interpreted as a direct measure of parochial altruism. Interest reflects the motivation to get more information about a certain topic (Schwab and Schwender, 2010) and could also reflect an increased desire to restore a sense of control in face of a threat induction (Fritsche et al., 2008; Jonas et al., 2014). However, if the desire to know more about a potential threat instead of the interest in parochial altruistic content would underlie our pattern, we would also find larger interest in the Islamic extremist videos, as Islamic extremism is perceived as particularly threatening (Frindte and Haußecker, 2010).

In that line it has to be noted that the reliability of our perceived persuasiveness measure aggregated for the video blocks was slightly below $\alpha>0.70$. Although previous research obtained higher reliability scores for this scales (Rieger et al., 2013), and the reliability was good, $\alpha>80$, when all items per video instead of the aggregated scales per Block were considered, future studies should include additional measures of persuasiveness. Overall, future research is necessary to bridge our findings on the perceived persuasiveness of extremist propaganda with research on liking of parochial altruist persons (Greenberg et al., 2001; Pyszczynski et al., 2006). Our scale measured increased sympathy with the propagators, hence, our findings should also be reflected in greater liking of extremist propagators (Decety and Chaminade, 2003). Relatedly, we did not measure attitudes toward the propagated message directly. Yet, Igartua et al. (2003) found that convincingness of a persuasive video was associated with agreement to these videos' messages and we have initial evidence from an unpublished Bachelor thesis that our perceived persuasiveness scale is associated with the agreement to rightwing statements. Kasztelan (unpublished bachelor thesis) found that the perceived persuasiveness of right-wing videos correlated 
at $r>0.56, p>0.001$ with the agreement to statements in a propaganda video such as "our folk impoverishes everyday more and more meanwhile others live in clover" or "Only a folk without identity becomes an easy victim of the capital." Finally, studying to what extent MS affects hormones that control parochial altruism such as oxytocin (De Dreu et al., 2010, 2011) or testosterone (Reimers and Diekhof, 2015) would provide meaningful insights into the biological mechanisms underlying our observations.

\section{Conclusion}

Overall, our study provides initial evidence that the interest in and perceived persuasiveness of extremist propaganda works

\section{References}

Abbink, K., Brandts, J., Herrmann, B., and Orzen, H. (2012). Parochial altruism in inter-group conflicts. Econ. Lett. 117, 45-48. doi: 10.1016/j.econlet.2012.04.083

Altemeyer, B., and Hunsberger, B. (1992). Authoritarianism, religious fundamentalism, quest, and prejudice. Int. J. Psychol. Relig. 2, 113-133. doi: 10.1207/s15327582ijpr0202-5

Arendt, F. (2015). Effects of right-wing populist political advertising. J. Med. Psychol. 1-30. doi: 10.1027/1864-1105/a000139

Arrow, H. (2007). The sharp end of altruism. Science 318, 581-582. doi: $10.1126 /$ science. 1150316

Ashour, O. (2010). Online de-radicalization? Countering violent extremist narratives: message, messenger and media strategy. Perspect. Terror. 4, 15-19.

Axelrod, R., and Hamilton, W. D. (1981). The evolution of cooperation. Nature 211, 1390-1396. doi: 10.2436/20.1501.02.87

Bartsch, A., and Schneider, F. (2014). Entertainment and politics revisited: how non-escapist forms of entertainment can stimulate political interest and information seeking. J. Commun. 3, 369-396. doi: 10.1111/jcom.12095

Bayrisches Staatsministerium des Inneren für Bau und Verkehr. (2014). Verfassungsschutzbericht 2014 [Report on the Protection of the Constitution 2014]. München: Bayrisches Staatsministerium des Inneren für Bau und Verkehr.

Bernhard, H., Fischbacher, U., and Fehr, E. (2006). Parochial altruism in humans. Nature 442, 912-915. doi: 10.1038/nature04981

Böhm, R., Rusch, H., and Gürek, Ö. (2015). What makes people go to war? Defensive intentions motivate retaliatory and preemptive intergroup aggression. Evol. Hum. Behav. doi: 10.1016/j.evolhumbehav.2015.06.005

Bornstein, G., and Erev, I. (1994). The enhancing effect of intergroup competition on group performance. Int. J. Confl. Manag. 5, 271-183. doi: 10.1108/eb022747

Bornstein, G., Gneezy, U., and Nagel, R. (2002). The effect of intergroup competition on group coordination: an experimental study. Games Econ. Behav. 41, 1-25. doi: 10.1016/S0899-8256(02)00012-X

Bowles, S. (2008). Conflict: altruism'S midwife. Nature 456, 326-327. doi: 10.1038/456326a

Brewer, M. B., and Carporael, L. R. (2006). An evolutionary perspective on social identity: revisiting groups, in Evolution and Social Psychology, ed. M. Schaller, J. A. Simpson, and D. T. Kendrick (Philadelphia: Psycology Press), 143-161.

Brown, R., González, R., Zagefka, H., Manzi, J., and Cehajic, S. (2008). Nuestra culpa: collective guilt and shame as predictors of reparation for historical wrongdoing. J. Pers. Soc. Psychol. 94, 75-90. doi: 10.1037/0022-3514.94.1.75

Choi, J.-K., and Bowles, S. (2007). The coevolution of parochial altruism and war. Nature 318, 636-640. doi: 10.1126/science.1144237

Cosmides, L., Tooby, J., and Kurzban, R. (2003). Perceptions of race. Trends Cogn. Sci. 7, 173-179. doi: 10.1016/S1364-66130300057-53

Das, E., Bushman, B. J., Bezemer, M. D., Kerkhof, P., and Vermeulen, I. E. (2009). How terrorism news reports increase prejudice against outgroups: a terror management account. J. Exp. Soc. Psychol. 45, 453-459. doi: 10.1016/j.jesp.2008.12.001 according to a parochially altruistic mechanics. Existential threats affected the response to extremist propaganda capitalizing on the recipient's national identity but left the response to comparable videos addressing them as out-group members unaffected. Our study thus provided evidence for meaningful insights resulting from an evolutionary perspective on media psychology and propaganda research. We hope that future studies will address the questions that can be drawn from our results.

\section{Supplementary Material}

The Supplementary Material for this article can be found online at: http://journal.frontiersin.org/article/10.3389/fpsyg. 2015.01222

Decety, J., and Chaminade, T. (2003). Neural correlates of feeling sympathy. Neuropsychologia 41, 127-138. doi: 10.1016/S0028-3932(02)00143-4

Decker, O., Kiess, J., and Brähler, E. (2012). Die Mitte Im Umbruch [The Middle in Turmoil], ed. R. Melzer (Bonn: Friedrich-Ebert Stiftung).

De Dreu, C. K. W. (2012). Oxytocin modulates cooperation within and competition between groups: an integrative review and research agenda. Horm. Behav. 61, 419-428. doi: 10.1016/j.yhbeh.2011.12.009

De Dreu, C. K. W., Balliet, D., and Halevy, N. (2014). Parochial cooperation in humans: forms and functions of self-sacrifice in intergroup conflict. $A d v$. Motivat. Sci. 1, 1-47. doi: 10.1016/bs.adms.2014.08.001

De Dreu, C. K. W., Dussel, D. B., and Velden, F. S. T. (2015). In intergroup conflict, self-sacrifice is stronger among pro-social individuals, and parochial altruism emerges especially among cognitively taxed individuals. Front. Psychol. 6:572. doi: 10.3389/fpsyg.2015.00572

De Dreu, C. K. W., Greer, L. L., Handgraaf, M. J. J., Shalvi, S., Van Kleef, G., Baas, M., Ten Velden, F. S., et al. (2010). The neuropeptide oxytocin regulates parochial altruism in intergroup conflict among humans. Science 328, 14081411. doi: $10.1126 /$ science. 1189047

De Dreu, C. K. W., Greer, L. L., Van Kleef, G. A., Shalvi, S., and Handgraaf, M. J. J. (2011). Oxytocin promotes human ethnocentrism. Proc. Natl. Acad. Sci. U.S.A. 108, 1262-1266. doi: 10.1073/pnas. 1015316108

Dilanian, K., and Bennett, B. (2013). Experts See Home-Grown Terror in Boston Case. Available at: http://articles.latimes.com [accessed April 19, 2013].

Field, A. (2013). Discovering Statistics Using IBM SPSS Statistics, 4th Edn. London: Sage Publications, Ltd.

Fischer, P., Greitemeyer, T., Kastenmüller, A., Frey, D., and Oßwald, S. (2007). Terror salience and punishment: does terror salience induce threat to social order? J. Exp. Soc Psychol. 43, 964-971. doi: 10.1016/j.jesp.2006. 10.004

Frindte, W., Boehnke, K., Kreikenbronn, H., and Wagner, W. (2012). Lebenswelten Junger Muslime in Deutschland [Lifeworlds of Young Muslims in Germany]. Berlin: Bundesministerium des Inneren.

Frindte, W., and Haußecker, N. (2010). Inszenierter Terrorismus [Staged Terrorism]. Wiesbaden: Verlag für Sozialwissenschaften Springer Fachmedien. doi: 10.1007/978-3-531-92579-0

Fritsche, I., Jonas, E., and Fankhänel, T. (2008). The role of control motivation in mortality salience effects on ingroup support and defense.J. Pers. Soc. Psychol. 95, 524-541. doi: 10.1037/a0012666

Fuchs, M. (2003). Rechtsextremismus von Jugendlichen: Zur Erklärungskraft Verschiedener Theoretischer Konzepte [Right-Wing Extremism of Young Adults: Explanative Power of Different Theoretical Concepts]. Kölner Z. Soz. Sozialpsychol. 55, 654-678. doi: 10.1007/s11577-003-0116-3

Ginges, J., and Atran, S. (2009). What motivates participation in violent political action: selective incentives or parochial altruism? Ann. N. Y. Acad. Sci. 1167, 115-123. doi: 10.1111/j.1749-6632.2009.04543.x

Ginges, J., Hansen, I., and Norenzayan, A. (2009). Religion and support for suicide attacks. Psychol. Sci. 20, 224-230. doi: 10.1111/j.1467-9280.2009. 02270.x 
Ginges, J., Hansen, I., and Norenzayan, A. (2010). Religious belief, coalitional commitment, and support for suicide attacks. Evol. Psychol. 8, 346-349. doi: $10.1177 / 147470491000800303$

Glaser, S. (2013). Rechtsextremismus Online. Mainz: Jugendschutz.net.

Glynn, C. J., Hayes, A. F., and Shanahan, J. (1997). perceived support for one's opinions and willingness to speak out: a meta-analysis of survey studies on the spiral of silence. Public Opin. Q. 61, 452-463. doi: 10.1086/297808

Godall, H. L. (2010). How Progressive Academics Can Challenge Extremists and Promote Social Justice. Walnut Creek, CA: Left Coast Press.

Greenberg, J., Pyszczynski, T., and Solomon, S. (1986). "The causes and consequences of a need for self-esteem: a terror management theory," in Public Self and Private Self, ed. R. F. Baumeister (New York, NY: Springer-Verlag), 189-212.

Greenberg, J., Schimel, J., Martens, A., and Solomon, S. (2001). Sympathy for the devil: evidence that reminding whites of their mortality promotes more favorable reactions to white racists. Motivat. Emot. 25, 113-133. doi: 10.1023/A:1010613909207

Halevy, N., Bornstein, G., and Sagiv, L. (2008). In-group love' and 'out-group hate' as motives for individual participation in intergroup conflict: a new game paradigm. Psychol. Sci. 19, 405-411. doi: 10.1111/j.1467-9280.2008.02100.x

Halverson, J. R., Corman, S. R., and Godall, H. L. (2011). Master Narratives of Islamist Extremism. London: Palgrave Macmillan Publishing.

Hamilton, W. D. (1964a). The genetical evolution of social behaviour. II. J. Theor. Biol. 7, 17-52. doi: 10.1016/0022-5193(64)90039-90036

Hamilton, W. D. (1964b). The genetical evolution of social behaviour I. J. Theor. Biol. 7, 1-16. doi: 10.1016/0022-5193(64)90038-4

Hayes, A. F. (2012). Process: A Versatile Computational Tool for Observed Variable Mediation, Mod Eration, and Conditional Process Modeling. Available at: http:// www.afhayes.com

Hewstone, M., Rubin, M., and Willis, H. (2002). Bias. Annu. Rev. Psychol. 53, 575-604. doi: 10.1146/annurev.psych.53.100901.135109

Hogg, M. A. (2014). From uncertainty to extremism: social categorization and identity processes. Curr. Dir. Psychol. Sci. 23, 338-342. doi: $10.1177 / 0963721414540168$

Hogg, M. A., Adelman, J. R., and Blagg, R. D. (2010). In the face of uncertainty: an uncertainty-identity theory account of religiousness. Pers. Soc. Psychol. Rev. 14, 72-83. doi: 10.1177/1088868309349692

Igartua, J. J., Cheng, L., and Lopes, O. (2003). To think or not to think: two pathways towards persuasion by short films on AIDS prevention. J. Health Commun. 8, 513-528. doi: 10.1080/716100420

Jonas, E., Martens, A., Kayser, D. N., Fritsche, I., Sullivan, D., and Greenberg, J. (2008). Focus theory of normative conduct and terror-management theory: the interactive impact of mortality salience and norm salience on social judgment. J. Pers. Soc. Psychol. 95, 1239-1251. doi: 10.1037/a0013593

Jonas, E., Mcgregor, I., Klackl, J., Agroskin, D., Fritsche, I., Holbrook, C., et al. (2014). "Threat and defense: from anxiety to approach," in Advances in Experimental Social Psychology, 49th Edn, eds J. M. Olson and M. P. Zanna (Burlington: Elsevier Inc.), 219-286. doi: 10.1016/b978-0-12-800052-6. 00004-4

Kruglanski, A. W., Bélanger, J. J., Gelfand, M., Gunaratna, R., Hettiarachchi, M., Reinares, F., et al. (2013). Terrorism-a (self) love story: redirecting the significance quest can end violence. Am. Psychol. 68, 559-575. doi: $10.1037 / \mathrm{a} 0032615$

Kugler, M. B., and Cooper, J. (2010). Still an american? mortality salience and treatment of suspected terrorists. J. Appl. Soc. Psychol. 40, 3130-3147. doi: 10.1111/j.1559-1816.2010.00694.x

Kurzban, R., Tooby, J., and Cosmides, L. (2001). Can race be erased? Coalitional computation and social categorization. Proc. Natl. Acad. Sci. U.S.A. 98, $15387-$ 15392. doi: 10.1073/pnas.251541498

Lasswell, H. D. (1927). Propaganda Techniques in the World War. London: Paul Kegan.

Lewis, E. St. (1903). Catch-line and argument. Book Keeper 15:124ff.

Lickel, B., Schmader, T., Curtis, M., Scarnier, M., and Ames, D. R. (2005). Vicarious shame and guilt. Group Process. Intergr. Relat. 8, 145-157. doi: $10.1177 / 1368430205051064$

McCauley, C., and Moskalenko, S. (2008). Mechanisms of political radicalization: pathways toward terrorism. Terror. Polit. Violence 20, 415-433. doi: $10.1080 / 09546550802073367$
Monin, M. M. (2009). Mortality Salience and Smokers Reactions to Anti-Smoking Messages. Pittsburgh: Duquesne University.

Ohler, P., and Nieding, G. (2006). "An evolutionary perspective on entertainment," in Psychology of Entertainment, eds B. M. Jenkins and P. Vorderer (Mahwah, NJ: Lawrence Erlbaum Associates), 432-434.

Pettigrew, T. F. (1995). Subtle and blatant prejudice in western Europe. Eur. J. Soc. Psychol. 25, 57-75. doi: 10.1002/ejsp.2420250106

Petzel, T., Wagner, U., Nicolai, K., and Van Dick, R. (1997). Ein Kurzes Instrument Zur Messung Der Autoritarismus-Neigung [A Short Instrument for Measuring Authoritarianism]. Gruppendynamik 28, 251-258.

Piff, P. K., Martinez, A. G., and Keltner, D. (2012). Me against we: in-group transgression, collective shame, and in-group-directed hostility. Cogn. Emot. 26, 634-649. doi: 10.1080/02699931.2011.595394

Postmes, T., Spears, R., and Lea, M. (1998). Breaching or building social boundaries: side effects of computer-mediated communication. Commun. Res. 25, 689-715. doi: 10.1177/009365098025006006

Pyszczynski, T., Abdollahi, A., Solomon, S., Greenberg, J., Cohen, F., and Weise, D. (2006). Mortality salience, martyrdom, and military might: the great satan versus the axis of evil. Pers. Soc. Psychol. Bull. 32, 525-537. doi: $10.1177 / 0146167205282157$

Pyszczynski, T., Greenberg, J., and Solomon, S. (1999). A dual-process model of defense against conscious and unconscious death-related thoughts: an extension of terror management theory. Psychol. Rev. 106, 835-845. doi: 10.1037/0033-295X.106.4.835

Pyszczynski, T., Rothschild, Z., and Abdollahi, A. (2008). Terrorism, violence, and hope for peace: a terror management perspective. Curr. Dir. Psychol. Sci. 17, 318-322. doi: 10.1111/j.1467-8721.2008.00598.x

Raven, J. C. (1998). Raven's Progressive Matrices: SPM Plus Test Booklet, eds S. Bulheller and H. O. Häcker (Oxford: Psychology Press).

Reimers, L., and Diekhof, E. K. (2015). Testosterone is associated with cooperation during intergroup competition by enhancing parochial altruism. Front. Neurosci. 9:183. doi: 10.3389/fnins.2015.00183

Rieger, D., Frischlich, L., and Bente, G. (2013). In Cooperation with the Terrorism/Extremism Research Unit (FTE) of the German Federal Criminal Police Office (Bundeskriminalamt). Propaganda 2.0: Psychological Effects of Right-Wing and Islamic Extremist Internet Videos. Cologne: Wolters Kluwer Deutschland GmbH.

Rieger, D., Frischlich, L., Högden, F., Schramm, K., Kauf, R., and Tappe, E. (2015). Appreciation in the face of death: meaningful films buffer against death-related anxiety. J. Commun. 65, 351-372. doi: $10.1111 /$ jcom. 12152

Riolo, R. L., Cohen, M. D., and Axelrod, R. (2001). Evolution of cooperation without reciprocity. Nature 414, 441-443. doi: 10.1038/35106555

Rosenberg, M. (1965). Society and the Adolescent Self-Image. Princeton, NJ: Princeton University Press.

Rosenblatt, A., Greenberg, J., Solomon, S., Pyszczynski, T., and Lyon, D. (1989). Evidence for terror management theory: i. the effects of mortality salience on reactions to those who violate or uphold cultural values. J. Pers. Soc. Psychol. 57, 681-690. doi: 10.1037/0022-3514.57.4.681

Roth, F., Weinmann, C., Schneider, F., Hopp, F., and Vorderer, P. (2014). Seriously entertained: antecedents and consequences of hedonic and eudaimonic entertainment experiences with political talk shows on TV. Mass Commun. Soc. 17, 379-399. doi: 10.1080/15205436.2014.891135

Rusch, H. (2013). Asymmetries in altruistic behavior during violent intergroup conflict. Evol. Psychol. 11, 973-993. doi: 10.1177/147470491301 100504

Rusch, H. (2014). The evolutionary interplay of intergroup conflict and altruism in humans: a review of parochial altruism theory and prospects for its extension. Proc. R. Soc. 281:20141539. doi: 10.1098/rspb.2014. 1539

Schindler, S., Reinhard, M. A., and Stahlberg, D. (2013). Tit for tat in the face of death: the effect of mortality salience on reciprocal behavior. J. Exp. Soc. Psychol. 49, 87-92. doi: 10.1016/j.jesp.2012.06.002

Schwab, F. (2007). Evolutionäres Denken: Missverständnisse, Trugschlüsse Und Richtigstellungen [Evolutionairy Thinking: Missunderstandings, False Conclusions, and Corrections]. Z. Medienpsychol. 19, 140-144. doi: 10.1026/1617-6383.19.4.140 
Schwab, F. (2010). Medien, Emotionen Und Unterhaltung [Media, Emotions and Entertainment]. Diskurs 51, 14-17.

Schwab, F., and Schwender, C. (2010). "The descents of emotions in media. darwinian perspectives," in The Routledge Handbook of Emotions and Mass Media, eds K. Döveling, C. von Scheve, and E. A. Konijn (London: Routledge).

Sibley, C. G., and Duckitt, J. (2008). Personality and prejudice: a metaanalysis and theoretical review. Pers. Soc. Psychol. Rev. 12, 248-279. doi: $10.1177 / 1088868308319226$

Slater, M. D., and Rouner, D. (2002). Entertainment-education and elaboration likelihood: understanding the processing of narrative persuasion. Commun. Theory 12, 173-191. doi: 10.1111/j.1468-2885.2002.tb00265.x

Stephan, W. G., Diaz-Loving, R., and Duran, A. (2000). Integrated threat theory and intercultural attitudes: Mexico and the United States. J. Cross Cult. Psychol. 31, 240-249. doi: 10.1177/0022022100031002006

Tangney, J. P., Wagner, P., Fletcher, C., and Gramzow, R. (1992). Shamed into anger? The relation of shame and guilt to anger and self-reported aggression. J. Pers. Soc. Psychol. 62, 669-675. doi: 10.1037/0022-3514.62.4.669

Tooby, J., and Cosmides, L. (2001). Does beauty build adapted minds? Toward an evolutionary theory of aesthetics, fiction, and the arts. Substance 30, 6-27. doi: 10.1353/sub.2001.0017

Trivers, R. L. (1971). The Evolution of Reciprocal Altruism. Q. Rev. Biol. 46, 83-57. doi: 10.1086/406755

Vorderer, P. (2006). "Psychology of entertainment," in Psychology of Entertainment, eds J. Bryant and P. Vorderer (Mahwah, NJ: Lawrence Erlbaum Associates).

Wagner, U., Christ, O., and Kühnel, S. M. (2002). "Diskriminierendes verhalten: es beginnt mit abwertungen," in Deutsche Zustände, ed. W. Heitemeyer (Frankfurt: Suhrkamp).

Wahba, A., and Simon, J. (2014). Und Packt Die Babyflaschen Ein [and Bring Baby Bottles]. Die Zeit 41, 61.

Weise, D. R., Pyszczynski, T., Cox, C. R., Arndt, J., Greenberg, J., Solomon, S., et al. (2008). Interpersonal politics: the role of terror management and attachment processes in shaping political preferences: research article. Psychol. Sci. 19, 448-455. doi: $10.1111 / j .1467-9280.2008 .02108 . x$
Weisel, O., and Böhm, R. (2015). Ingroup love' and 'outgroup hate' in intergroup conflict between natural groups. J. Exp. Soc. Psychol. 60, 110-120. doi: 10.1016/j.jesp.2015.04.008

West, S. A., El Mouden, C., and Gardner, A. (2011). Sixteen common misconceptions about the evolution of cooperation in humans. Evol. Hum. Behav. 32, 231-262. doi: 10.1016/j.evolhumbehav.2010. 08.001

Wilner, A., and Dubouloz, C.-J. (2009). Homegrown terrorism and transformative learning: an interdisciplinary approach to understanding radicalization. Paper presented at the Canadian Political Science Association Conference, Vol. 22, (Ottawa: University of Ottawa), 33-51.

Wisman, A., and Koole, S. L. (2003). Hiding in the crowd: can mortality salience promote affiliation with others who oppose one's worldviews? J. Pers. Soc. Psychol. 84, 511-526. doi: 10.1037/0022-3514.84.3.511

Xiaojing, X., Xiangyu, Z., Xiaoying, W., and Han, S. (2009). Do you feel my pain? Racial group membership modulates empathic neural responses. J. Neurosci. 29, 8525-8529. doi: 10.1523/JNEUROSCI.2418-09.2009

Yuki, M., and Yokota, K. (2009). The primal warrior: outgroup threat priming enhances intergroup discrimination in men but not women. J. Exp. Soc. Psychol. 45, 271-274. doi: 10.1016/j.jesp.2008.08.018

Zahavi, A. (1995). Altruism as a handicap-the limitations of kin selection and reciprocity. J. Avian Biol. 26, 1-3. doi: 10.2307/3677205

Conflict of Interest Statement: The authors declare that the research was conducted in the absence of any commercial or financial relationships that could be construed as a potential conflict of interest.

Copyright (C) 2015 Frischlich, Rieger, Hein and Bente. This is an open-access article distributed under the terms of the Creative Commons Attribution License (CC BY).

The use, distribution or reproduction in other forums is permitted, provided the original author(s) or licensor are credited and that the original publication in this journal is cited, in accordance with accepted academic practice. No use, distribution or reproduction is permitted which does not comply with these terms. 